\title{
6. Mental illness, journalism investigation and the law in Australia and New Zealand
}

\section{ABS SIMRACII}

Mental illness, its terminologies, definitions, voluntary and compulsory treatment regimes, and its interface with the criminal justice system are defined and regulated remarkably differently across the 10 Australian and New Zealand jurisdictions. This presents a legislative and policy nightmare for the investigative journalist attempting to explain the workings of the mental health system or follow a case, particularly if the individual's life has taken them across state or national borders. This article considers the extent to which legal restrictions on identification and reportage of mental health cases in Australia and New Zealand inhibit the pursuit of 'bloodhound journalism' - the persistent pursuit of a societal problem and those responsible for it. It recommends the development of resources assisting journalists to navigate the various mental health regulatory regimes. It also calls for the opening of courts and tribunals to greater scrutiny so that the public can be better educated about the people affected by mental illness and the processes involved in dealing with them, and better informed about the decisions that deprive their fellow citizens of their liberty.

Keywords: investigative journalism, health, justice system, media law, mental illness, public policy

\section{MARK PEARSON}

Centre for New Media Research and Education, Bond University

ENTAL ILLNESS is a major health issue throughout
Australasia, with almost half of New Zealanders having a
mental disorder at some time in their lives and one fifth of adult Australians experiencing the symptoms of mental disorder every year (Dowell et. al, 2009, p. xi; AIHW, 2010, p. iii). As such, it is worthy of thorough 
investigation and research by the news media on a range of fronts, including health, education, public policy, politics, economics and law and order. In Australia, researchers have suggested there has been an improvement in both the number and quality of mental illness and suicide-related media coverage after more than a decade of the Mindframe National Media Initiative sponsored by the Australian government (Pirkis et. al, 2008, p. 264). Similarly, a baseline study by McKenna et. al. (2010, p. 69) found a generally acceptable standard of suicidereportage in NewZealand andrecommended strongerliaison between the media and those working in mental health.

However, while there has been considerable reportage on the generalities of mental illness and public policy issues, government announcements, academic research, and one-off incidents such as suicides or crimes involving the mentally ill (Francis et. al, 2001), secrecy provisions in both Australia and New Zealand have limited genuine in-depth reporting following cases through the mental health and criminal justice systems. This article considers the extent to which legal restrictions on identification and reportage of mental health cases in Australia and New Zealand inhibit the pursuit of what Tanner (2002, pp. xix-xx) calls 'bloodhound journalism' - the persistent pursuit of a societal problem and those responsible for it.

\section{Mental illness - definitional and systemic differences}

Governments in Australia have recently been attempting to develop uniform policies and protocols for managing mental illness, outlined in the National Mental Health Strategy (AIHW, 2010, p. 8) but there has been little progress in bringing the different legislative and regulatory systems into alignment. As the Senate Standing Committee on Community Affairs (2008, p. 10) noted:

Mental health policy in Australia sits within the context of the federated system. While reforms such as the National Mental Health Strategy are articulated at a national level and with the cooperation of all jurisdictions, the reality remains that implementation has been variable in light of each state and territory's own policy context and history.

Mental illness, its terminologies, definitions, voluntary and compulsory treatment regimes, and its interface with the criminal justice system are defined and regulated remarkably differently across the ten Australian and New Zealand jurisdictions. This presents a legislative and policy nightmare for the investigative journalist attempting to explain the workings of the mental 
health system or follow a case, particularly if the individual's life has taken them across state or national borders.

The definitions of 'mental illness' and 'mental disorder' vary markedly. For example, Victoria's Mental Health Act defines 'mental illness' as 'a medical condition characterised by a significant disturbance of thought, mood, perception or memory'. Queensland's law offers a slightly differing version as 'a condition characterised by a clinically significant disturbance of thought, mood, perception or memory'. Western Australia personalises it and makes it a suffering by stating it to 'a person has a mental illness if the person suffers from a disturbance of thought, mood, volition, perception, orientation or memory that impairs judgment or behaviour to a significant extent'. The Northern Territory's Mental Health and Related Services Act has this lengthy definition:

a condition that seriously impairs mental functioning in one or more areas of thought, mood, volition, perception characterised by the presence of at least one of the following symptoms: delusions; hallucinations; serious disorders of the stream of thought; serious disorders of thought form; serious disturbances of mood or by sustained or repeated irrational behaviour that may be taken to indicate the presence of at least one of the symptoms referred to.

Some jurisdictions also list separate definitions of 'mental disorder', while others do not use this term. New Zealand's Mental Health (Compulsory Assessment and Treatment) Act 1992 defines a 'mental disorder' as: 'an abnormal state of mind (whether of a continuous or an intermittent nature), characterised by delusions, or by disorders of mood or perception or volition or cognition, of such a degree that it:

(a) Poses a serious danger to the health or safety of that person or of others; or

(b) Seriously diminishes the capacity of that person to take care of himself or herself.

The Australian Capital Territory's Mental Health (Treatment \& Care) Act 1994 calls it 'a disturbance or defect, to a substantially disabling degree, of perceptual interpretation, comprehension, reasoning, learning, judgment, memory, motivation or emotion'. 
All this may seem pedantic, given a journalist's role is to explain and interpret complex information for the lay reader, but such definitional distinctions are important to determining whether an individual comes within the bounds of the legislation which usually contains publication and identification restrictions as detailed below. Further, using a label like 'mental illness' or 'mental disorder' or using such terms interchangeably can have implications for the publisher in other areas of media law such as defamation and sub judice contempt - also operational within the same jurisdictions. The incorrect use of such a term can cause damage to the reputation of an individual or might be seen to run the risk of limiting their chance of a fair trial in pending criminal proceedings.

Added to such definitional confusion are the systemic differences in the regulation of mental health in the ten Australian and New Zealand jurisdictions, Australian Commonwealth law, that of its six states and two territories, and New Zealand law. This project was particularly concerned with the processes and proceedings involving so-called 'forensic' patients - variously defined as those 'whose health condition has led them to commit, or be suspected of, a criminal offence' (AIHW, 2010, p. 140) or as those who were unfit for trial or of unsound mind when they committed an offence (Mental Health Act 2000 (Qld), Schedule 2) - and those who were not facing a criminal trial but were facing the issue or review of 'compulsory treatment orders' by mental health tribunals or their equivalent bodies. Journalists might need to investigate either in their work. They would need to cover stories on the former when major crimes have been committed in their communities and the accused has been adjudged either mentally unfit to plead or has been found not guilty by reason of insanity or their equivalents. There are many such patients. There were 618 mental health hospital beds occupied by forensic patients in Australia in 2007-08, and many more such individuals in prison (AIHW, 2010, p. 150). At June 30, 2007, there were 309 forensic patients in NSW alone (Howard, 2008, p. 13). Australia-wide there just over one million community mental health care service contacts with involuntary patients in 2007-08 — quite separate from those admitted to institutions as patients (AIHW, 2010, p. 38). Journalists might encounter individuals subject to compulsory treatment orders when following their cases as part of broader mental health stories or investigating them individually to probe the fairness and integrity of the tribunals' processes. The Senate Standing Committee on Community Affairs (2008, p. 33) noted with concern the lack of uniformity of laws in these areas. 
The committee recognises that harmonising state and territory Mental Health Acts will have many advantages, including providing greater clarity and certainty regarding compulsory mental health treatment Australia wide. It encourages state, territory and Commonwealth governments to work towards achieving nationally consistent legislation as soon as possible.

Such uniformity has been slow in evolving in other areas of the law, so journalists will need to navigate these different regimes when researching mental health stories for the foreseeable future. The different jurisdictions also vary on whether their mental health tribunals handle both 'involuntary mental health consumers' and 'forensic patients' - those who have been referred by the courts as defined above. In NSW, Queensland and the ACT the mental health tribunals or their equivalent handle both forensic and non-criminal cases. The processes are separated in the other states, the Northern Territory and in New Zealand. Tasmania appears to have some overlap with its separate Forensic Tribunal chaired by the president of the Mental Health Tribunal.

\section{Reporting and identification differences across jurisdictions}

It is important for journalists entering this domain to be aware of what they can and cannot report about a mental health case. If such cases are not the central focus of a story, they may be the lifeblood of more general stories about the mental health system and process. Reporters need to know whether they can attend proceedings and identify individuals who have been the subject of compulsory treatment orders, whether or not those individuals have the authority to give permission themselves, and whether they can follow such cases through the system by reporting upon tribunals' periodic reviews of their cases. Sadly, there is a tangle of legislation related to this area, even without paying regard to the media relations policies of the various health and justice departments, which can be a major impediment to reportage in their own right. For example, Pearson and McLean (2010, p. 26) reported there were 75 media and public relations officers in the Queensland departments of health and justice alone in 2008.

The main aim of this project funded by the Mindframe National Media Initiative, was to examine the identification and publication restrictions on the forensic and involuntary mental health proceedings in the courts and mental 
health tribunals. This project has involved essentially a legislative analysis, although the review of the literature necessitated considerable reading of mental health literature in the various jurisdictions, law reform and parliamentary submissions and reports, academic research and some key legal case reports. The complexity of the material also prompted some telephone calls to courts and mental health administrators who were helpful with background information on the reality of the process in the respective states and territories. Much more could be done in this regard, as foreshadowed in suggestions for further research towards the end of this article.

The findings - and their implications for the principle of 'open justice' in our legal system - will be explored in detail in a subsequent article. However, the overall findings are summarised here to demonstrate the complexity of the situation facing journalists reporting in the field. While there are exceptions, there generally seems to be a basic adherence to the principle of 'open justice' (reportable proceedings) in the forensic or criminal appeal process, although suppression orders are sometimes issued, while the mental health tribunal (or equivalent) processes for involuntary patients usually have stringent nonpublication, non-identification, and secrecy provisions with substantial fines or jail terms applicable in the breach.

The respective jurisdictional differences are:

- In NSW, s.162 of the Mental Health Act bans the identification of anyone involved in either Mental Health Tribunal or forensic proceedings, however s.151(3) requires the tribunal's proceedings to be held in public unless otherwise ordered. This implies the possibility of media reports of such matters without identifying data on individuals involved, a similar situation to the reportage of juvenile court cases in most jurisdictions.

- Queensland has a complicated 28 day rule for publication of Mental Health Court proceedings involving those not sent to trial or appealing, while reporting of those whose trial proceeds is banned until the trial is over (Mental Health Act ss.524 and 526). However, there is no publication of Mental Health Review Tribunal proceedings permitted at s.460 and non-publication stipulated at s.524, although it may be allowed with permission without any identification at s.525. Oddly, s.525(1)c prevents publication without permission of Mental Health Court inquiries into unlawful detention of patients, certainly a matter of interest to the media. 
- Tasmanian legislation closes all mental health proceedings unless special permission has been granted (Mental Health Act s.64 and s.74k).

- Victoria's whole system is under review, but the early 2011 situation was that forensic matters were likely reportable while in the courts under open justice principles, but ss.33 and 34 of the Mental Health Act closed Mental Health Review Board proceedings and ban publication without permission.

- Western Australia's court processes for forensic patients also seem to be open under s.171 of the Criminal Procedure Act establishing open court as the default, although for treatment orders Mental Health Review Board hearings are closed under Schedule 2, clause 12 of the Mental Health Act and clause 13 bans all identification material. That state also appears to have a close relationship between the Prisoners Review Board and the Mentally Impaired Accused Review Board, with all communication with the latter channelled via the former.

- In South Australia, the forensic processes while in court appear relatively open, although that state is renowned for its high incidence of suppression orders. However, the Mental Health Act s.107 bans any reporting of proceedings without permission of the board and s.106 forbids disclosure of personal information.

- The Northern Territory has a similar level of open justice for its criminal cases and their reporting, but the Mental Health Review Tribunal proceedings are closed under s.135 of the Mental Health and Related Services Act 1998, and s.139 prevents identification of parties without both their consent and leave from the tribunal.

- The Australian Capital Territory Civil and Administrative Tribunal (ACAT) has both forensic and involuntary treatment review powers, and its hearings are closed under s.86 of the Mental Health (Treatment and Care) Act 1994. Criminal court matters appear generally open.

- The Commonwealth Crimes Act 1914 allows for State or Territory court administration of diminished responsibility related to federal crimes, with appeals to courts in those jurisdictions applying federal law. 
- New Zealand also has separation of the criminal process from the compulsory treatment order process under its Criminal Procedure (Mentally Impaired Persons) Act 2003 and its Mental Health (Compulsory Assessment and Treatment) Act 1992. Under s.24, proceedings for compulsory orders are not open to the public. Applications for compulsory treatment orders are recommended to be conducted by a Family Court judge under s.17 of the latter Act, implying Family Court Act s.11B restrictions on identification would also apply.

In short, the issue of open justice and the extent to which court and tribunal proceedings involving mentally ill people should be reportable is of a scale that could quite easily justify $\mathrm{PhD}$ research, and this is in fact being undertaken by Andrew Caple from Queensland University of Technology who is examining open justice and the Queensland mental health system for his doctoral thesis (Caple, 2009). Different jurisdictions seem to have made varying attempts at striking a balance between the public interest in open, transparent and accountable proceedings for the involuntary treatment of psychiatric and forensic patients and their competing right to privacy. Further, the rights of others to be informed of the outcome of such proceedings, including victims of their crimes or behaviour, appear to receive varying priorities in different jurisdictions. Of course, it is not just a case of the patient's privacy rights versus the public's right to know. Patients also have the important issue of their liberty at stake in such proceedings, which might well be compromised by a secret, unreportable tribunal or court process. Such issues will be explored in forthcoming publications by the author.

This research area cannot be divorced from the related field of guardianship processes and legislation. Unfortunately, the funding and timelines available for this project did not allow for the inclusion of the various guardianship laws in these jurisdictions. The Queensland Law Reform Commission's inquiry into confidentiality in the guardianship system over the past several years has led to its publication of R67 Review of Guardianship Laws (QLRC, 2010). That report discussed open justice in that context (at pp. 78-84), as did an earlier report (QLRC, 2007, 3.23-3.57). Guardianship laws are certainly a complicating factor in the equation for journalists investigating the field. For example, in South Australia there is a cross-reference from the Mental Health Act 2009 to the Guardianship and Administration Act 1993, s.81 of 
which bans reports of proceedings and s. 80 of which requires all involved in the administration of the Act to maintain confidentiality. There is also the matter of corrective services legislation in most jurisdictions prohibiting the interviewing of prisoners without permission from authorities. For example, in Queensland, s.132 of the Corrective Services Act 2006 makes it an offence to interview, record or photograph a prisoner inside or outside a corrective services facility, or photograph a part of the prison without the permission of the authorities. Since 1996, at least six journalists have been charged under this Queensland law or its predecessor. Documentary maker Anne Delaney was given a 12-month $\$ 750$ good behaviour bond under the provision in 2005 for allegedly interviewing a prisoner at the Brisbane Women's Correctional Centre (Pearson \& Polden, 2011, p. 169). Given the huge overlap between mental health and criminal justice and the use of prisons to house the mentally ill on compulsory treatment orders in a secure environment in some jurisdictions, the relevance of these laws becomes clear (White \& Whiteford, 2006).

\section{Prospects for 'bloodhound journalism' and further research}

Quality 'bloodhound journalism' examining the mental health system and even individual cases can still be undertaken despite this somewhat intimidating and complex array of anti-publication law and policy. It is a little comforting that the non-publication and non-identification laws under many of these Acts have rarely been prosecuted, but that does not mean they will not be in the future. Investigative journalists in some jurisdictions will be able to cover proceedings without identifying the individuals involved, using pseudonyms and pixellation of images to achieve their ends. In other jurisdictions they will be able to identify the individuals with their permission, that of their guardians, or perhaps that of the court on application. Permission can also be sought to cover tribunal proceedings with the various permissions in order. Most jurisdictions allow the coverage of the court proceedings in criminal cases involving those unfit to plead or pleading not guilty by reason of unsound mind or insanity, however journalists should be on the alert for suppression orders that might be issued in such cases. Further, the review of their mental health status by professionals and tribunals at a later stage of the process may not be reportable or the individuals may not be identifiable. While this study has focussed mainly on forensic and involuntary patients, it is important to note that even voluntary mental health patients are covered by confidentiality and non-publication orders in most jurisdictions. Thus, even 
interviews with individuals at the lower end of the mental illness spectrum might be fraught.

The complexities of the legislation, combined with guardianship and prisons legislation outside the ambit of this research, moot for concrete reporting guidelines for reporters in all jurisdictions when following a mental health story leading to such proceedings.

Clearly, this project has raised numerous issues of importance to journalists, mental health professionals, mental health consumers, the justice system and the broader community. There are several avenues for further research, including:

- Policy analysis of the Hansard documents and parliamentary committee deliberations and submissions leading to the cited legislation to better understand the legislators' balancing of the relative rights and interests involved.

- Interviews with journalists, editors and media lawyers on the application of these laws and the impact of identification and reporting restrictions on their work.

- Detailed case analyses of the many tribunal and court cases citing the above legislation and exploring the rationale for any suppression orders issued in relation to them.

- As this project has been predominantly limited to a legislation analysis, there is also a need for the study of media access policies within the various health departments and prison systems to attempt to ascertain the extent to which journalists can contact and interview both forensic and involuntary patients for related stories.

The field is ripe for further research and is also overdue for legislative reform opening the courts and tribunals to greater scrutiny so that the public can be better educated about the people affected by mental illness and the processes involved in dealing with them, and better informed about the decisions that deprive so many of their fellow citizens of their liberty.

\section{References}

Australian Institute of Health and Welfare (AIHW). (2010). Mental health services in Australia 2007-08. Mental health series no. 12. Cat. no. HSE 88. Canberra: AIHW. Retrieved on 20 December 2010, from www.aihw.gov.au/publications/ hse/88/11415.pdf . 
Caple, Andrew (2009). An analysis of open justice and privacy in Queensland's Mental Health Review Tribunal. Doctoral proposal summary, Queensland University of Technology. Retrieved on 20 December 2010, from www.qcjc.com.au/research/ download/6/research/mental-health-review-tribunal-1/open-justice-and-privacyin-qlds-forensic-mental-health-system.pdf .

Dowell AC, Garrett S, Collings S, McBain L, McKinlay and E, Stanley J. (2009). Evaluation of the Primary Mental Health Initiatives: Summary report 2008. Wellington: University of Otago and Ministry of Health. Retrieved on 20 December, 2010, from www.moh.govt.nz/moh.nsf/pagesmh/9281/\$File/evaluation-primarymental-health-Initiatives-summary-report-jul09.pdf .

Francis, C., Pirkis, J., Dunt. D. \& Blood R. W. (2001). Mental health and illness in the media: A review of the literature. Canberra, ACT: Commonwealth Department of Health and Ageing.

Howard, D. (2008). The detention of forensic patients in New South Wales and other Australian jurisdictions - some new developments and some thoughts on uniformity. Paper presented to the International Criminal Law Conference in Sydney, 11 October, 2008. Retrieved on 20 December 2010, from www.icms.com.au/ crimlaw/ForensicPatients.doc

McKenna, B., Thom, K., Edwards, G. Nairn, R. O’Brien, A. \& Leary, I. (2010.) Reporting of New Zealand media - Content and case study analysis. Auckland: Centre for Mental Health Research, The University of Auckland.

Pearson, M. \& McLean, H. (2010). Quantifying government media relations in Queensland. Public Communication Review, 1(2). Retrieved on 20 December 2010, from epress.lib.uts.edu.au/ojs/index.php/pcr/article/viewFile/1636/1920

Pearson, M. \& Polden, M. (2011). The journalist's guide to media law (4 th Ed.). Sydney: Allen \& Unwin.

Pirkis, J., Blood, R.W., Dare, A. \& Holland, K. (2008). The Media Monitoring Project media reporting and portrayal of suicide and mental health and illness in Australia: Improvements, challenges and prospects. Canberra: Australian Government Department of Health and Ageing. Retrieved on 20 December 2010, from www. mindframe-media.info/client_images/900018.pdf

Queensland Law Reform Commission (2010). R67 A review of Queensland's guardianship laws. QLRC, Brisbane. Retrieved on 20 December 2010, from www.qlrc. qld.gov.au/Publications.htm.

Queensland Law Reform Commission (2007). Report 62, volume 1: Public justice, private lives: A new approach to confidentiality in the guardianship system. QLRC, Brisbane. Retrieved on 20 December 2010, from www.qlrc.qld.gov.au/reports/ R62Vol1.pdf .

Senate Standing Committee on Community Affairs (2008, September). Towards recovery: mental health services in Australia. Canberra: Commonwealth of Australia. Available: www.aph.gov.au/senate/committee/clac_ctte/mental_health/ report/report.pdf 
Tanner, S. (2002). Journalism investigation and research. Frenchs Forest: Pearson Education Australia.

White, P. \& Whiteford, H. (2006) Prisons: mental health institutions of the 21st century? Medical Journal of Australia 185(6): 302-303.

\section{Legislation cited}

Corrective Services Act 2006 (Queensland)

Crimes (Mental Impairment and Unfitness to be Tried) Act 1997 (Victoria)

Crimes Act 1900 (Australian Capital Territory)

Crimes Act 1914 (Clth)

Crimes Act 1961 (New Zealand)

Criminal Code Act (Northern Territory)

Criminal Justice (Mental Impairment) Act 1999 (Tasmania)

Criminal Law (Mentally Impaired Accused) Act 1996 (Western Australia)

Criminal Law Consolidation Act 1935 (South Australia)

Criminal Procedure (Mentally Impaired Persons) Act 2003 (New Zealand)

Family Courts Act 1980 (New Zealand)

Guardianship and Administration Act 1993 (South Australia)

Mental Health \& Related Services Act 1998 (Northern Territory)

Mental Health (Compulsory Assessment \& Treatment) Act 1992 (New Zealand)

Mental Health (Forensic Provisions) Act 1990 (NSW)

Mental Health (Treatment \& Care) Act 1994 (Australian Capital Territory)

Mental Health Act 1986 (Victoria)

Mental Health Act 1996 (Tasmania)

Mental Health Act 1996 (Western Australia)

Mental Health Act 2000 (Qld)

Mental Health Act 2007 (NSW)

Mental Health Act 2009 (South Australia)

Sentencing Act 1991 (Victoria)

Mark Pearson is professor of journalism at Bond University Queensland, Australia. He is co-author (with Mark Polden) of The Journalist's Guide to Media Law (4th ed., Allen and Unwin, 2011). He blogs from journlaw. com and tweets from @journlaw. This project received funding under the Australian government's Mindframe National Media Initiative.

mpearson@staff.bond.edu.au 